The Life of Ignatius of Loyola represents a significant development in the self-understanding of the Society of Jesus by an author who was himself a founding member of the order and who was present throughout its rapid early evolution. His explanations of this evolution are interesting in themselves, but it is perhaps the unselfconscious literary evolution-from the founding texts of the Society (Spiritual Exercises, Acta of Ignatius, and Constitutions), which owe so much to medieval practices of rhetoric, to this more grammar-influenced textthat is most striking. The transposition of the charism of the Society from one cultural context to another, as it emerges from this Life, is well worth the further study and exploration that Pavur hopes to foster through this translation.

GILLES MONGEAU

Regis College, University of Toronto

\title{
Duncan-Jones, Katherine.
}

\section{Portraits of Shakespeare.}

Oxford: Bodleian Library, University of Oxford, 2015. Pp. ix, $126+39$ colour ill. ISBN 978-1-85124-405-8 (paperback) £14.99/US\$25.

In this short but telling book, British scholar Katherine Duncan-Jones weighs in on the increasingly fractious matter of portraiture associated with Shakespeare, an ongoing source of friction among Shakespeareans chasing the Holy Grail of an image of the bard painted from life. The field is littered with venal exchanges, dubious claims, glancing and self-serving scholarship, and polysyllabic slapdowns, as in eminent English art historian (and former director of the National Portrait Gallery) Roy Strong calling Stanley Wells's suspect assertions about the Cobbe Portrait's authenticity "codswallop"-in The Guardian no less (April 2009).

Duncan-Jones has a stake in the tussles too, and she has rightly critiqued the Cobbe, in this book and elsewhere, with some panache-a critique that has elicited howls of protestation from the rival camp and demands for apology. It's not often that academic debate in the arts and humanities, much less early modern studies, gets this tetchy. Yet with Shakespeare's life-image the stakes are high, involving substantial material consequences including institutional self-interest, academic and curatorial careers, and significant revenue streams derived from 
licensing, touring, merchandising, and on-site tourist traffic. A far cry, in other words, from scholastic debates over the metaphysics of Hamlet's melancholia or Lady Macbeth's moral depravity, and a situation driven, in part, by the rush to capitalize on historic increases in the value of art in the global marketplace.

Beautifully illustrated and clearly written, Duncan-Jones takes her readers through an array of main contenders, from the Gheerart Janssen (attributed) bust in Holy Trinity Church at Stratford, through the Martin Droeshout engraving that embellishes the First Folio (1623), the infamous Chandos portrait, and disputed and commemorative portraits-including the Sanders Portrait, the so-called "Canadian" contender of which I will have more to say further on. Closing with so-called disputed paintings is a tad misleading as virtually all of these visual representations are open to debate-or, at the very least, require careful contextualization.

The two most unquestioned "likenesses" of the Bard, for instance, the Droeshout and the Janssen, as James Knapp notes in Shakespeare and the Power of the Face, are problematic in terms of their figural realities, and have largely left viewers unsatisfied and wanting more. Verisimilitude, let alone aesthetic accomplishment, is hardly characteristic of these images. The Droeshout is a technically banal engraving, posthumously executed by a young engraver. The Janssen bust is a stodgy, if not downright ugly, representation. Duncan-Jones rightly asks, "did it [the Janssen] always seem slightly clumsy, provincial and artistically second-rate, or may it have been quite a handsome effigy when brand new?" (35). The short answer is "no": the Janssen is a graceless bit of work-a poorly executed effigy, not a life-representation of Shakespeare.

Duncan-Jones is on sketchier ground when she turns her attention to the Chandos portrait, held by the National Portrait Gallery in London. The founding portrait of the Gallery (NPG1) also happens to be the most ubiquitous image of Shakespeare on the planet. The main drive behind the book appears to be an ill-considered attempt to re-invigorate this portrait's claim to authenticity, while selectively setting aside key information that undermines that very argument. Duncan-Jones makes no mention, for instance, of how the Chandos has been over-painted; of how it is not an Elizabethan painting stylistically, and how attempts to place it as a very early Jacobean painting are highly problematic; how there is nothing physically on (or in) the painting to link it directly with Shakespeare; how its genealogy is suspect especially given its provenance via the Caroline and Restoration playwright, William Davenant. The latter is 
well-known for his dubious claims about being Shakespeare's bastard son, as reported by John Aubrey, a mediocre writer's conceit in which Davenant avers that "he writ with the very spirit that did Shakespeare, and seemed contented enough to be thought his Son."

When it comes to the Canadian-owned Sanders portrait, Duncan-Jones makes a number of assertions that would barely pass muster in the draft of a Wikipedia entry. Neglectful of the arm's-length work of the Canadian Conservation Institute on the science of the portrait and the extensive, groundbreaking research done by Worcestershire genealogist Pam Hinks that ties the Sanders family to Shakespeare's inner circle, Duncan-Jones quite shockingly imputes a "sinister possibility" to the fact that a strip of wood the length of the right side of the portrait has cracked off, saying that it "was deliberately removed at an unknown date, perhaps at the time the paper label was concocted, because it identified the sitter as someone other than Shakespeare" (104). No proof is offered of deliberate removal, not a shred of evidence offered to back the claim up. Nor does Duncan-Jones attend to the obvious proportions of the part broken off in relation to the overall size of the painted date (1603) in the upper right corner, which would have made adding a name highly improbable. That Duncan-Jones completely sidesteps the science behind the label, the only known extant document that fixes Shakespeare's birthday on April 23, 1564, calling it a "concoction," is shoddy work not worthy of a scholar of her distinction. She also takes a stab at the Sanders face as not being credibly that of a thirty-nine-year old - "It is generally felt that this sitter looks a good deal younger than that"-repeating NPG chief curator Tarnya Cooper's impressionistic affirmation about the sitter's age made in 2006. Anyone who has seen acclaimed documentarian Anne Henderson's 2009 film, Battle of Wills, yet to be shown in the UK, will know that such a claim about the age of the sitter is in explicit contradiction to multiple images from the period where apparent and real age diverge. To suggest that this is a generally held opinion based on one citation is simply embarrassing.

The book, however problematic, is still worth reading as exemplary of the critical challenges facing early modernists producing research in this contested area.

DANIEL FISCHLIN

University of Guelph 